\title{
Small island perspectives on climate change
}

\author{
Rory A. Walshe \\ Department of Geography, King's College London, UK \\ Institute for Risk and Disaster Reduction, University College London, UK \\ rory.walshe@kcl.ac.uk
}

\section{Charlotte Eloise Stancioff \\ Leiden University, The Netherlands \\ c.e.stancioff@arch.leidenuniv.nl}

\begin{abstract}
Islands and islanders are often misrepresented in the climate change discourse, oversimplifying their experiences and interactions with climate change. In reality, islands and islanders have far more complex relationships with climate change. This special thematic section presents eight papers that highlight local responses and localized impacts of climate change on islands, reiterating the importance of considering local community perspectives in small island contexts to overcome simplistic viewpoints. Such perceptions and perspectives are increasingly being recognized as offering a valuable contribution to climate change adaptation, particularly to counter the misrepresentation of small islands as vulnerable or passive, and the disregard for the fact that climate change is a global, as well as continual process. This special thematic section further demonstrates that island research is well placed to address the disproportionate concentration of perspectives and opinions of climate change from the Global North and adds to the calls for increased efforts to give a voice to island communities of all kinds.
\end{abstract}

Keywords: climate change, interdisciplinary research, island studies, perceptions, small islands

https://doi.org/10.24043/isj.56

(C) 2018-Institute of Island Studies, University of Prince Edward Island, Canada.

\section{Introduction}

On 23 September 2017, Dominica Prime Minister Roosevelt Skeritt addressed the UN General Assembly and emotionally declared that his island "Eden is broken." He described the devastation wrought by the 2017 hurricanes as comparable to a war zone, and so he was reporting from the "frontlines of the war on climate change" (UN-News, 2017). While climate change is often at the forefront of geopolitical discussions, small island voices such as this are, for the most part, in the minority. This dearth of local small island perspectives can lead to the misrepresentation of island populations as vulnerable or passive, as well as disregard for the fact that climate change is a global and continual process.

While islands are among the places least responsible for the emission of greenhouse gasses leading to climate change, they are predicted to suffer a range of associated adverse effects, including increased temperatures, 'extreme' weather events, and sea level rise (IPCC, 2012; United Nations, 2010; UNEP, 2014). It is often described that the impacts of climate change will be more severe on islands due to their small size, limited resource base, growing populations, relative isolation, or economies of scale (see Briguglio, 1995; ECLAC, 2011; Méheux et al., 2007; Pelling \& Uitto, 2001; United Nations, 2010). However, the discourse of island vulnerability and the frequently used archetype of islands at the mercy of climate 
change is problematic, as it simplifies and misrepresents island realities by presenting the severity of climate impact as a focal point. The papers presented in this special thematic section demonstrate that in reality islands and islanders have considerably more complex relationships with climate and climate change. This special thematic section therefore attempts to overcome the simplistic viewpoint by examining the perceptions of islanders themselves.

While there is not adequate space to fully dissect the term 'island' here, the authors recognize the imprecise definition of 'island' (see Jędrusik, 2011), taken in the broadest sense in this special thematic section in order to look beyond SIDS alone. Research on perspectives on and perceptions of climate change from island communities of all kinds (and island research more broadly) has typically been on the periphery, marginalized, or ignored. Increasingly, small islands are being portrayed as 'canaries in the coal mine' (Hanna \& McIver, 2014), the first to experience the impacts of climate change and therefore the first to offer potential insights into adaptation (Thompson, 2008).

Simplistic island tropes should be avoided in research into island adaptation and the default position of the islands and islanders themselves being defined and encapsulated by their peripheral, immobile, and isolated nature should be rejected. Island research has repeatedly shown that reality differs strongly from such tropes (Grydehøj, 2014), and islanders can also be characterized by their movement and agency (Bernardie-Tahir, 2014). Moreover, considering the diversity of islands across the globe, lumping small islands together into one category (for example as Small Island Developing States (SIDS)) disregards the diversity that exists, marginalizing outliers and inconsistencies in descriptors (Kelman \& West, 2009). This complexity reveals a need to look beyond simple metrics or measurements. For example, in a comparison of location-controlled Gross Domestic Products (GDP) between SIDS and other states, SIDS actually had higher GDPs (Easterly \& Kraay, 2000), so clearly economic metrics such as this do not tell the whole story, and these 'conventional wisdom' onedimensional labels of islands are often misleading.

The potential impacts of climate change on small islands remain grave, but while this should not be forgotten, it is important to avoid immediately associating 'islandness' with vulnerability and 'problematizing' small islands (Kelman \& Khan, 2013). Smallness as a characteristic does not automatically result in vulnerability (Baldachino, 2005; Kelman, 2007). Often, the same descriptors used to justify the labelling of an island as vulnerable, also result in characteristics of resilience. For example, isolation and small population size are suggested as indicators of vulnerability due to the danger of a single physical hazard impacting a large proportion of total population, and the prospect of relief or aid being far away, yet community cohesion often develops out of this same characteristic (Gaillard, 2007). Equally high exposure to physical environmental stressors over long periods of time clearly presents vulnerability, yet rich local knowledge can result from long histories of responding to these risks (Mercer et al., 2012; Walshe \& Nunn, 2012).

One key emerging question is: Does the vulnerability rhetoric surrounding island communities invite adaptation or promote a popularized doomsday approach? Studies of sea level rise on islands are compelling and sometimes go 'viral' (see for example Albert et al., 2016 and the resultant reporting; Jun, 2016). Linked to the image or idea of sinking islands, there is increasing interest in the potential for migration associated with climate change, which is explored in a growing body of literature (Burkett, 2011; Klepp \& Herbeck, 2016). However, while there is risk of inundation, the narrative of islands sinking or disappearing as well as the 'canary in the coalmine' framing can result in an "eco-colonial gaze" (Farbotko, 2010), where island self-determination is undermined by global, academic, or diplomatic attention and representation as a microcosm.

Much of the climate change discourse regarding small islands has been based on global or regional studies predicting higher sea levels (Walsh et al., 2012) or sea surface temperature (Ruosteenoja et al., 2003; IPCC, 2013). While of course relevant, the application of global 
scale environmental change data to local level island communities often does not align. Therefore, drawing broad-brush conclusions on the implications of climate change for all small islands is likely to create issues. Each island experiences climate change differently depending on historic precedents and local context, and so caution is needed when extrapolating local findings to the wider context.

There is an important difference, however, between the top-down application of global data to islands and looking for wider connections emerging from island contexts and research. As noted by Grydehøj $(2017$, p. 8), the question of scale and the importance of expanding the reach of island studies research is essential to avoid "missing the forest for the trees, the archipelago for the islands." Collections of research (this section included) might benefit from being viewed as inter- and tele-connected, as portrayed by Hau'ofa (1993) as a 'sea of islands', from which common and shared lessons can be drawn. Certainly, islands are already and increasingly acting together at the policy level in response to climate change. For example, in 2016, President Taneti Maamau of Kiribati and other Pacific Island leaders pushed for early entry into the Paris Agreement at the United Nations General Assembly. The consideration of both a highly specific local context and a lens of larger scales should not necessarily be portrayed as in conflict, but rather as complimentary of each other.

The articulation of connection and scale (rather than the portrayal of islands as only isolated) is particularly important, since much of the discourse surrounding the vulnerability of islands assumes that they represent closed systems, which are insulated from global connections. In fact (particularly considering the ubiquitous spread of neo-liberal capitalism) closed systems do not exist, and instead islands are often 'cross-roads' for trade and tourism, partly due to their insularity (Baldacchino, 2004). The consideration of scale is also important because both risk and characteristics of vulnerability and resilience emerge from processes and loci which can be distant in space and time (Cutter \& Finch, 2008, p. 76), both exogenous and indigenous (Lewis, 2009), and sometimes (particularly in regard to climate change) are of no fault of the islanders themselves. Therefore both resilience and vulnerability should not be assumed as inherent to SIDS, but identifying both is necessary and important (Kelman \& West, 2009), and should be carefully applied when considering the often apodictic manner with which these labels are ascribed.

Therefore, perhaps island studies research must ask how it can provide progressive investigations while balancing the daily needs of island communities with the realities of climate change. This special thematic section consists of papers that focus on island perspectives on and perceptions of climate.

\section{The importance of considering local island perceptions on and experiences of climate}

As responses to climate change need to be grounded in local perceptions and understandings, such perceptions are increasingly valorized as offering a valuable contribution to understanding the effect and impact of climate change (Glantz, 1988; Leiserowitz, 2006; Lindell \& Perry, 2003). It is also important to note that the examination of local perceptions and the interactions between humans, climate, weather, and the environment are not new (for early literature, see Glantz, 1986; Watsuji, 1988; Weickmann \& Seybold, 1940). Local perceptions and perspectives are also important due to the danger of misattributing environmental changes, such as sea level rise, to climate change alone, when instead a combination of local and global factors may be the cause (Ballu et al., 2011; Webb \& Kench, 2010). Whether or not local perceptions or attributions are scientifically 'accurate', they guide and influence the degree and nature of actions taken at the community level, including adaptation and responses to change (Lewis, 1990; Mortreux \& Barnett, 2009; Nunn, et al., 2016) and therefor need to be fully understood. 
In order to adequately understand and account for local perceptions of climate and climate change, a longue durée approach is suggested. This is an examination of history that focuses on the long-term structures and combines elements of both event and process and an analysis of historical discourses in an effort uncover the long-standing and slowly (often imperceptibly) changing relationships between people, culture, and the world (García-Acosta, 2016). A longue durée offers an insight into past responses to climate on islands and can provide valuable information today for societies that must cope with similar challenges (Bankoff, 2004; Glantz, 2003). It also positions climate change impacts in the context of other factors, natural processes, and patterns, and in so doing exposes that both share the same root vulnerability (O'Brien et al., 2004). This shows that the vanishing of islands is a continual phenomenon with historical precedent, which can sometimes be uncovered by local knowledge or island geo-mythology (Nunn, 2009). Such an approach can also deliver an analysis of the development and interactions of small island discourses over time (Grote, 2010), as well as an understanding of social adaptation processes that unfold across long periods (Adamson et al., 2018; Bankoff, 2004; Glantz, 1988).

Moreover, while there is a growing body of literature concerning dire climate change forecasts, imminent exposure to climate change effects, and the lack of political and related resources for coping with those effects (Betzold, 2010; Docherty \& Giannini, 2009; Kothari, 2014), for the most part this concerns island countries and SIDS. In many cases the extraterritorial lands of primarily mainland countries-whether near or far-are left at the margins of analyses, raising many questions concerning the postcolonial experience of climate change for 'overseas' territories, dependent islands, or islands which are not SIDS.

This again demonstrates the importance of a longue durée perspective, considering small islands, colonial history, and their interaction (and power dynamics) with industrial nations. Many small islands were formally colonized by nations that now play pivotal roles in climate politics on the international stage. For example, Paris hosted the United Nations Framework Convention on Climate Change (UNFCCC) Conference of the Parties (COP) in December 2015, pushing its own central government's agenda. Martinique and Guadeloupe are administered as overseas departments of France. However, Martinique and Guadeloupe experience, and will continue to experience, very different climate change impacts than mainland France. This rightly engenders questions regarding the role of France in the climate debates and concerns of power and status.

This special thematic section asks: What does climate change mean for small island communities? What are the everyday climate change-related impacts felt by islanders? This special thematic section delivers multidisciplinary examples of research that demonstrate the importance of new approaches and perspectives, as well as locally grounded research. To best understand how climate change is perceived by islanders, the associated impacts are understood as the everyday, involving not only environment, but also social structures, island politics, local economies, or in sum, daily livelihoods.

\section{Content review}

The papers in this special thematic section examine a wide geographical range of islands (see Figure 1), with three in the South Pacific (Beyerl et al., 2018; Perkins \& Krause, 2018; Perumal 2018), one in the Caribbean (Robinson, 2018), and one in the British Isles (Petzold, 2018). Two papers discuss islands groups which are extraterritorial lands and which are not SIDS (Ferdinand, 2018; Schwebel, 2018), and one takes a theoretical approach (Kelman, 2018). 


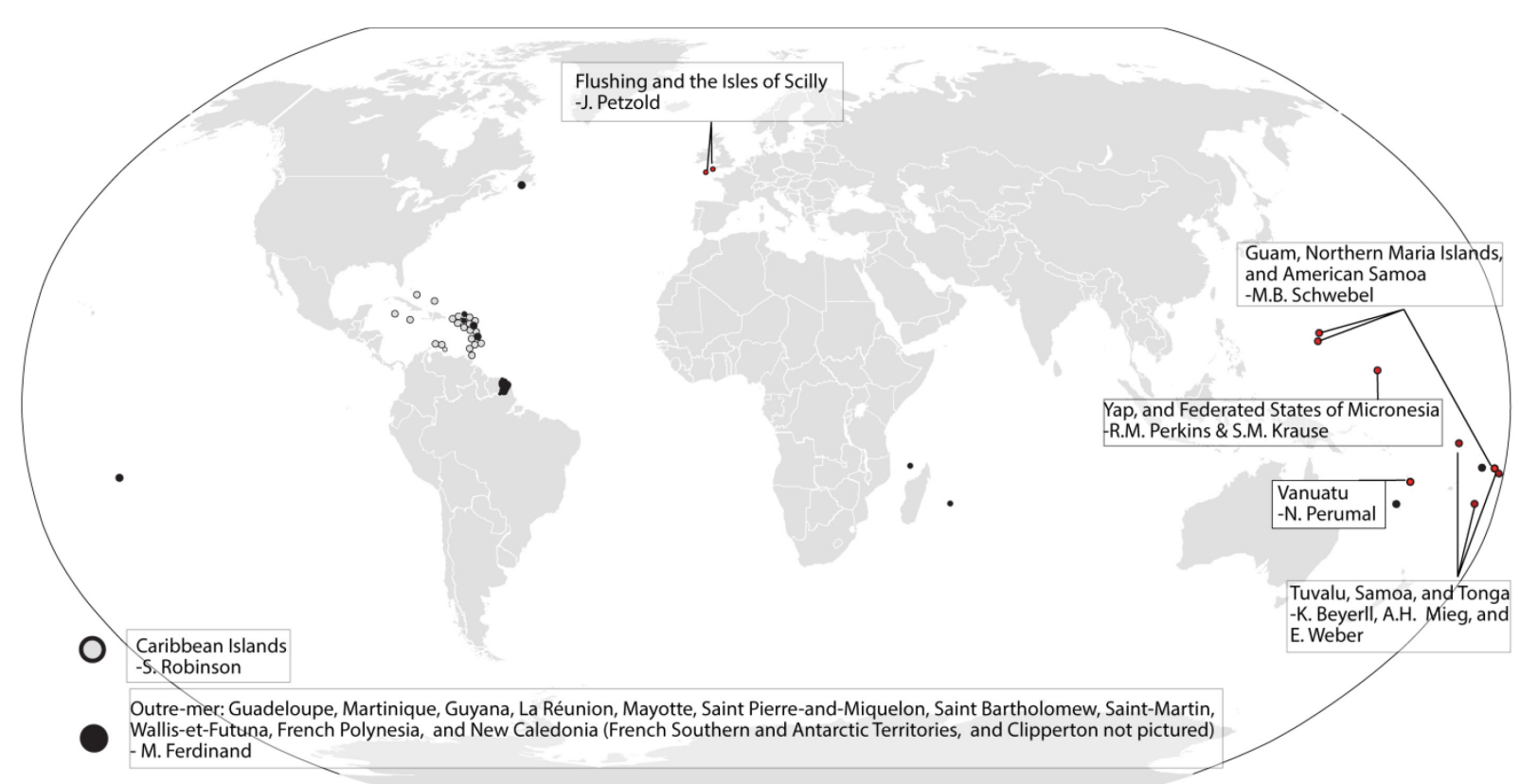

Figure 1: The different geographical focus areas of research papers in this section. (C) Rory Walshe \& Charlotte Eloise Stancioff, 2018)

The first paper, by Beyerl et al. (2018), involves a survey of communities in Tuvalu, Samoa, and Tonga, demonstrating that contrary to the mainstream perception that sea level rise is the primary concern, islanders instead prioritise drought, cyclones, and other waterrelated problems. The research also highlights how these communities have developed and implemented their own adaptation strategies and their expectations of the different stakeholders involved, including the government. The research demonstrates that the agency of local communities is by and large neglected, particularly in decisions regarding how to respond to such climate-related environmental change. Consequently, understanding (and accounting) for such perceptions of environmental change is not only needed to make effective and positive policy decisions but can also provide reliable data for scientific models.

Also from the South Pacific, Perumal (2018) draws from data collection in Vanuatu to challenge some of the reductionist narratives of climate change related migration and the often sensationalist use of the label 'refugee'. Specifically examining the perspective of ni-Vanuatu policymakers and climate activists, this research uncovers a reluctance to relocate at all due to climate change: Moving is truly a last resort, and the preference is for in situ adaptation and maintenance of cultural and livelihood continuity. These findings speak to the importance for self-determination and polices which place community perspectives at their centre.

The third paper from the South Pacific is authored by Perkins and Krause (2018), who conducted research in Yap State in the Federated States of Micronesia. This research demonstrates that the vulnerabilities and adaptive capacities within the separate islands of Yap State can only be understood as deeply rooted in the environmental and cultural components of their shared heritage. The paper also delves into the differences and potential interactions between the cultural heritage of the main island, and the outer islands. This again reinforces the importance of considering nuanced differences between and within island archipelagos and the importance of local scale when discussing climate impacts, since the cultural support networks described within will certainly be relied upon to lessen the severity of climate change impacts.

Moving from the South Pacific to the Caribbean and to a policy focus, Robinson (2018) provides an investigation of the perceptions of policymakers and the prioritised adaptation occurring at the national level and the limits to adaptation in Caribbean SIDS. The research reveals that Caribbean SIDS are focusing adaptation on hurricane impacts, rainfall, and 
drought patterns, and that the majority of adaptations are being undertaken in the coastal areas, with the sectors of water and agriculture also being focused on, and that the largest barrier to adaptation remains financial. Robinson (2018) also reminds us that perceptions and perspectives are important from all sectors of society, from rural communities to the 'community' of policymakers.

The need for perspectives is of course not limited to developing country contexts, as demonstrated by Petzold's (2018) paper examining coastal adaptation in two case studies, a coastal town and an archipelago, in Southwest England. The research dissects how local social structures and conflicting influences affect adaptability to sea-level rise in coastal communities through the concept of ecotones, areas where ecosystems overlap. Similar to Perkins and Krause (2018), this research finds deeply embedded social relationships, local traditions, and collective memory shaped by the interaction of communities and their environment, while a range of influences and issues (from demographic changes, political forces and economic) determine how environmental change is addressed.

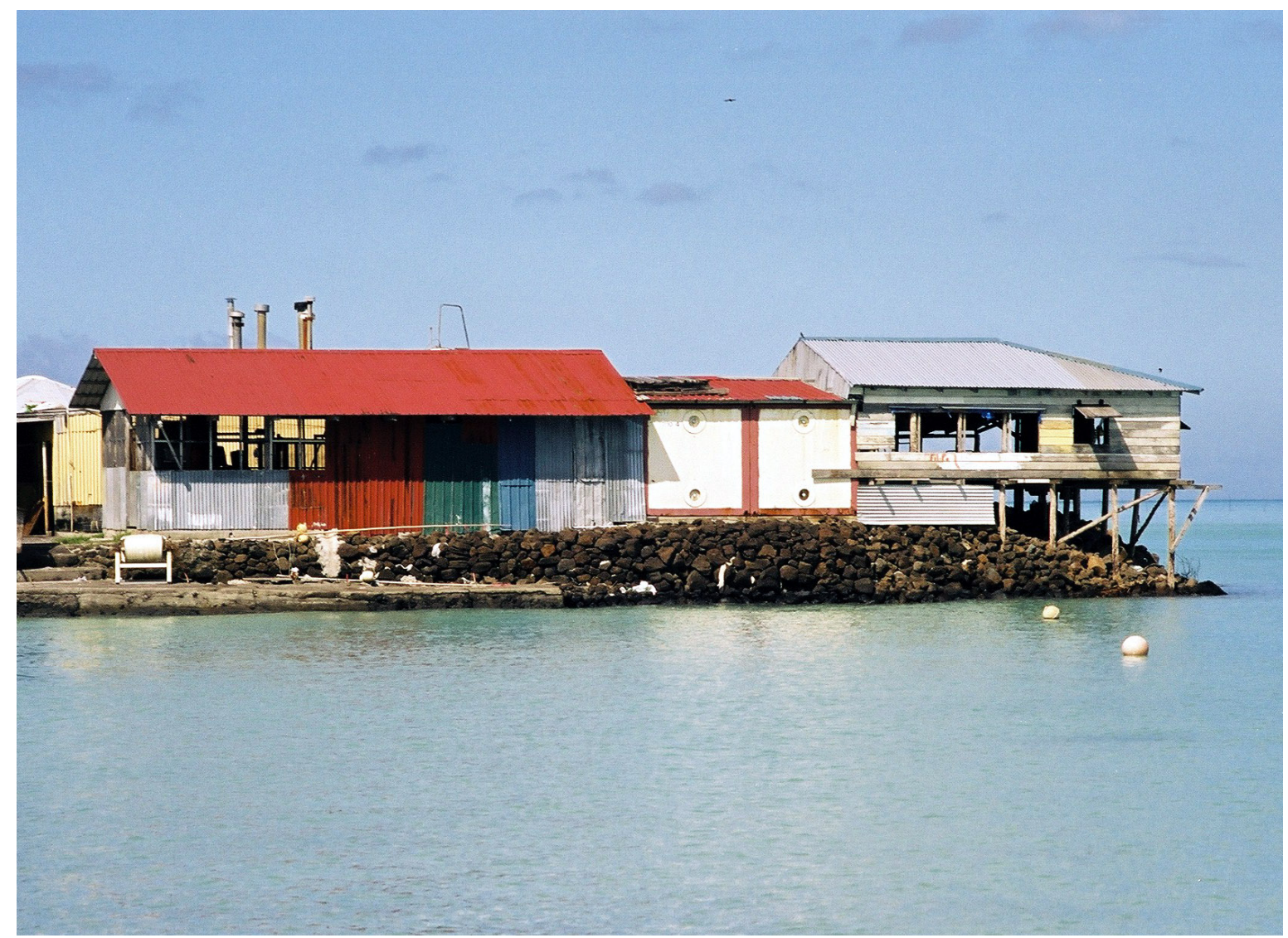

Figure 2: Houses close to the sea level on Upolu Island, Samoa, South Pacific (C Ilan Kelman)

In addition to place-specific research, wider regional analysis and the connection between common issues and solutions at a larger scale are needed. The papers described above have focused on perspectives and perceptions from the SIDS, however, as mentioned above, analysis of those islands excluded from this category, and the power dynamics involved in this exclusion, is not just welcome, but necessary. Such power dynamics are investigated in this special thematic section in two papers, the first by Ferdinand (2018) and the second by Schwebel (2018).

Ferdinand's (2018) paper delves into modern colonial and island perspectives in the case of France and the Outre-mer-specifically, the context of the vast differences between the climate change experienced by France and its administered territories. The article interrogates 
the role France takes in climate debates and concerns of power dynamics and status of small islands. The paper suggests an epistemic shift which puts the emphasis on the climate change inequalities and disparities of the French overseas territories with the European mainland, both in terms of causes and consequences.

A complementary paper is provided by Schwebel (2018) who analyses perceptions from policymakers in three United States Pacific territories; American Samoa, Guam, and the Northern Mariana Islands, regarding the issues and opportunities of post-colonial positionality between territories and colonial powers. The research shows that climate change is not necessarily at the forefront of concerns in the territories, but the respondents also feel constrained in their responses to climate change due to the lack of representation from the United States Federal Government at meetings or to exclusions from such meetings due to territorial sovereignty. The research also finds that for many islanders, the status of US territory was considered an asset due to the hypothetical protection and funding available in the case of major disaster.

Our final paper by Kelman (2018) cautions researchers and readers to avoid the compelling and understandable (based on many bleak testimonies) narrative of islandness being inherently linked to vulnerability. Kelman (2018) calls attention to the counternarratives challenging the image of inevitable SIDS communities becoming refugees, and instead suggests that justice and self-determination can provide the nuance and balance which unites these papers.

\section{Conclusion}

There is still a disproportionate concentration of opinions from the Global North, rather than the small islands where changes in weather, precipitation, or sea levels cause some of the worst damage. Equally, the academic community has provided many physical, instrumental and modelling details of climate change, and yet how climate change is perceived at local scales and levels remains poorly quantified.

This special thematic section aims to demonstrate the potential for islands studies research to address this balance. The papers included show that different island groups have different priorities and needs, which are often not accounted for. Instead climate change programs tend to didactically pass down directives and crowd out issues which are perceived as greater local concerns (Baldacchino \& Kelman, 2014; Walshe et al., 2017).

This special thematic section also adds to the assertion that broader climate change thinking (on islands and elsewhere) fails to acknowledge the diverse experience of climate risks, or the contested nature of many proposed solutions. Therefore, discussions about climate action should be based on this diversity of perceived risks and solutions (Forsyth, 2014). So far there is little evidence of this happening, and instead island communities are often uncritically approached, and any disagreements in perspective are smoothed over and social divisions are ignored (Auty, 2017; Baldacchino, 2013; Hoad, 2015; Hong, Wehi, \& Matsuda, 2013; Leunufna \& Evans, 2014; Persoon \& Simarmata, 2014; Rapaport, 2006).

The eight papers in this special thematic section contribute to these calls. On the broadest scale, they show great diversity in the way different islands and groups understand, experience and view climate change. Our inevitable recommendation is to add to those before us (Hofmann \& Lübken, 2015; Kelman, 2010; Lewis, 1990, 2009; Moncada et al., 2018) in calling for island scholarship to reject solipsism, and instead seek to understand the highly local and cultural perceptions, perspectives, and responses to climate change (Glantz, 1988; Hulme, 2016; Oliver-Smith, 1996; Rudiak-Gould, 2011, 2013). 


\section{Acknowledgements}

The authors wish to thank the University College London (UCL) Global Governance Institute for funding and supporting a workshop which lead to this special section, as well as Adam Grydehøj for his assistance as Island Studies Journal executive editor, Ilan Kelman for support throughout the process from its conception, and George Adamson for valuable constructive feedback on this guest editorial introduction.

\section{References}

Adamson, G.C.D., Hannaford, M.J., \& Rohland, E.R. (2018). Re-thinking the present: the role of a historical focus in climate change adaptation research. Global Environmental Change, 4(8), 195-205. https://doi.org/10.1016/j.gloenvcha.2017.12.003

Albert, S., Leon, J.X., Grinham, A.R., Church, J.A., Gibbes, B.R., \& Woodroffe, C.D. (2016). Interactions between sea-level rise and wave exposure on reef island dynamics in the Solomon Islands. Environmental Research Letters, 11(5), 054011. https://doi.org/10.1088/1748-9326/11/5/054011

Auty, R.M. (2017). Natural resources and small island economies: Mauritius and Trinidad and Tobago. The Journal of Development Studies, 53(2), 264-277. https://doi.org/10.1080/00220388.2016.1160063

Ballu, V., Bouin, M.N., Siméoni, P., Crawford, W.C., Calmant, S., Boré, J.M., Kanas, T. \& Pelletier, B. (2011). Comparing the role of absolute sea-level rise and vertical tectonic motions in coastal flooding, Torres Islands (Vanuatu). Proceedings of the National Academy of Sciences, 108(32), 13019-13022. https://doi.org/10.1073/pnas.1102842108

Baldacchino, G. (2013). Island landscapes and European culture: an 'island studies' perspective. Journal of Marine and Island Cultures, 2(1), 13-19. https://doi.org/10.1016/j.imic.2013.04.001

Baldacchino, G. (2005). Island Entrepreneurs: insights from exceptionally successful knowledge-driven SMEs from 5 European island territories. Journal of Enterprising Culture, 13(2), 145-170. https://doi.org/10.1142/S0218495805000100

Baldacchino, G. (2004). Moving away from the terms vulnerability and resilience in small islands. Wise Coastal Practices for Sustainable Human Development Forum, Paris, France: UNESCO.

Baldacchino, G., \& Kelman, I. (2014). Critiquing the pursuit of island sustainability: blue and green, with hardly a colour in between. Shima, 8(2) 1-21.

Bankoff, G. (2004). Time is of the essence: disasters, vulnerability and history. International Journal of Mass Emergencies and Disasters, 22(3), 23-42.

Bernardie-Tahir, N. (2014), Opening up the island: a 'counter-islandness' approach to migration in Malta. Introduction: theorizing migration and counter-islandness in Malta, Island Studies Journal, 9(1), 43-56.

Betzold, C. (2010). 'Borrowing' power to influence international negotiations: AOSIS in the climate change regime, 1990-1997. Politics, 30(3), 131-148. https://doi.org/10.1111/j.1467-9256.2010.01377.x

Beyerl, K., Mieg, A.H., \& Weber, E. (2018). Comparing perceived effects of climaterelated environmental changes and adaptation strategies for Tuvalu, Samoa and Tonga, Island Studies Journal, 13(1), 25-44.

Briguglio, L. (1995) Small island developing states and their economic vulnerabilities, World development, 23 (9), 1615-1632. https://doi.org/10.1016/0305-750X(95)00065-K 
Burkett, M. (2011). In search of refuge: Pacific islands, climate-induced migration, and the legal frontier. Asia Pacific East West Report (No. 98).

www.eastwestcenter.org/sites/default/files/private/api098.pdf

Cutter, S.L., \& Finch, C. (2008), Temporal and spatial changes in social vulnerability to natural hazards. Proceedings of the National Academy of Sciences of the United States of America, National Academy of Sciences, 105(7), 2301-2306. https://doi.org/10.1073/pnas.0710375105

Docherty, B., \& Giannini, T. (2009). Confronting a rising tide: a proposal for a convention on climate change refugees. Harvard Environmental Law Review, 33(1), 349-403.

Easterly, W., \& Kraay, A. (2000). Small states, small problems? Income, growth, and volatility in small states. World Development, 28(11), 2013-2027. https://doi.org/10.1016/S0305-750X(00)00068-1

ECLAC (2011). Study on the vulnerability and resilience of Caribbean small island developing states (SIDS). http://www.cepal.org/publicaciones/xml/4/45364/LCARL.354.pdf

Farbotko, C., (2010). Wishful sinking: disappearing islands, climate refugees and cosmopolitan experimentation. Asia Pacific Viewpoint, 51(1), 47-60. https://doi.org/10.1111/j.1467-8373.2010.001413.x

Ferdinand, M. (2018) Subnational climate justice for the French Outre-mer: postcolonial politics and geography of an epistemic shift, Island Studies Journal, 13(1), 119-134. https://doi.org/10.24043/isj.49

Forsyth, T. (2013). Community-based adaptation: a review of past and future challenges, Wiley Interdisciplinary Reviews: Climate Change, 4(5), 439-446.

Gaillard, J. (2007). Resilience of traditional societies in facing natural hazards. Disaster Prevention and Management: An International Journal, 16(4), 522-544. https://doi.org/10.1108/09653560710817011

García-Acosta, V. (2016). Disaster risk reduction including climate change adaptation in the longue durée. In J. Mercer, J.C. Gaillard, \& I. Kelman (Eds.) The Routledge handbook of disaster risk reduction including climate change adaptation (pp. 203-213) London: Routledge.

Glantz, M.H. (2003). Climate affairs: a primer. Washington D.C.: Island Press.

Glantz, M.H. (1988). An essay on the interactions between climate and society. Boulder: National Center for Atmospheric Research.

Glantz, M.H. (1986), Understanding how climate affect society and how society affects climate. Lecture notes for AMFUEL, 13 November, 1986.

Grote, J. (2010). The changing tides of small island states discourse - a historical overview of the appearance of small island states in the international arena. Verfassung und Recht in Übersee / Law and Politics in Africa, Asia and Latin America, 43(2), 164-191. https://doi.org/10.5771/0506-7286-2010-2-164

Grydehøj A. (2017). A future of island studies, Island Studies Journal, 12(1), 3-16. https://doi.org/10.24043/isj.1

Grydehøj A. (2014). Understanding island cities, Island Studies Journal, 9(2), 183-190.

Hanna, E.G., \& McIver, L (2014) Small island states: canaries in the coal mine of climate change and health. In C.D. Butler (Ed.) Climate change and global health (pp. 181-192) Wallingford: CABI. https://doi.org/10.1079/9781780642659.0181

Hau'ofa, E. (1994). Our sea of islands. The Contemporary Pacific, 6(1), 147-161

Hoad, D. (2015). Reflections on small island states and the international climate change negotiations. Island Studies Journal, 10(2), 259-262.

Hofmann, R., \& Lübken, U. (2015) Introduction: special issue 'Small islands and natural hazards'. Global Environment, 8(1), 4-15. https://doi.org/10.3197/ge.2015.080101 
Hong, S.K., Wehi, P., \& Matsuda, H. (2013). Island biocultural diversity and traditional ecological knowledge. Journal of Marine and Island Cultures, 2(2), 57-58. https://doi.org/10.1016/j.imic.2013.11.005

Hulme, M. (2016). Weathered cultures of climate. London: Sage.

IPCC (2012). Managing risks of extreme events and disasters to advance climate change adaptation: a special report of Working Groups I and II of the Intergovernmental Panel on Climate Change. Cambridge and New York: Cambridge University Press.

IPCC (2013). Climate Change 2013: the physical science basis: Working Group I contribution to the Fifth Assessment Report of the Intergovernmental Panel on Climate Change. T.F. Stocker, D. Qin, G.K. Plattner, M. Tignor, S.K. Allen, J. Boschung, A. Nauels, Y. Xia, V. Bex, \& P.M. Midgley (Eds.). Cambridge: Cambridge University Press.

Jun, C. (2016). Don't blame the Solomon Islands sinking all on climate change. Popular Science, 16 May. https://www.popsci.com/solomon-islands-study-author-downplaysclimate-change-link

Jędrusik, M. (2011) Island studies. island geography. but what is an island? Miscellanea Geographica 15(1), 201-212. https://doi.org/10.2478/v10288-012-0012-7

Kelman, I. (2018) Islandness within climate change narratives of small island developing states (SIDS). Island Studies Journal, 13(1), 149-166. https://doi.org/10.24043/isj.52

Kelman, I. (2010). Hearing local voices from small island developing states for climate change. Local Environment, 15(7), 605-619. https://doi.org/10.1080/13549839.2010.498812

Kelman, I. (2007). The island advantage: practices for prospering in isolation. id21 Insights, 70. http://www.ilankelman.org/articles1/id21no70.pdf

Kelman, I., \& Khan, S. (2013). Progressive climate change and disasters: island perspectives, Natural Hazards, 69 (1), 1131-1136. https://doi.org/10.1007/s11069-013-0721-z

Kelman, I., \& West, J.J. (2009). Climate change and small island developing states: a critical review. Ecological and Environmental Anthropology, 5(1), 1-16.

Klepp, S., \& Herbeck, J. (2016). The politics of environmental migration and climate justice in the Pacific region. Journal of Human Rights and the Environment, 7(1), 37-49. https://doi.org/10.4337/jhre.2016.01.03

Leiserowitz, A. (2006). Climate change risk perception and policy preferences: the role of affect, imagery, and values. Climatic Change, 77(1/2), 45-72. https://doi.org/10.1007/s10584-006-9059-9

Leunufna, S., \& Evans, M. (2014). Ensuring food security in the small islands of Maluku: a community genebank approach. Journal of Marine and Island Cultures, 3(2), 124-133. https://doi.org/10.1016/j.imic.2014.11.001

Lewis, J. (2009). An island characteristic. Shima, 3(1), 3-15.

Lewis, J. (1990). The vulnerability of small island states to sea level rise: the need for holistic strategies. Disasters, 14(3), 241-249. https://doi.org/10.1111/j.14677717.1990.tb01066.x

Lindell, M. \& Perry, R. (2003). Communicating environmental risk in multi-ethnic communities. London: Sage.

Méheux, K., Dominey-Howes, D., \& Lloyd, K. (2007). Natural hazard impacts in small Island developing states: a review of current knowledge and future research needs. Natural Hazards, 40(2), 429-446. https://doi.org/10.1007/s11069-006-9001-5

Mercer, J., Kelman, I., Alfthan, B. and Kurvits, T. (2012). Ecosystem-based adaptation to climate change in Caribbean small Island developing states: integrating local and external knowledge. Sustainability, 4(8), 1908-1932.

https://doi.org/10.3390/su4081908 
Moncada, S., Briguglio, L.P., Bambrick, H., \& Kelman, I. (2018). Guest editorial. International Journal of Climate Change Strategies and Management, 10(2), 214-216. https://doi.org/10.1108/IJCCSM-03-2018-184

Mortreux, C., \& Barnett, J. (2009). Climate change, migration and adaptation in Funafuti, Tuvalu, Global Environmental Change, 19(1), 105-112. https://doi.org/10.1016/j.gloenvcha.2008.09.006

Nunn P.D. (2009). Vanished islands and hidden continents of the Pacific. Honolulu: University of Hawaii Press.

Nunn, P.D., Runman, J., Falanruw, M., \& Kumar, R. (2016). Culturally grounded responses to coastal change on islands in the Federated States of Micronesia, northwest Pacific Ocean. Regional Environmental Change, 1(13), 428-439.

O'Brien, K., Eriksen, S., \& Schjolden, A. (2004). What's in a word? Conflicting interpretations of vulnerability in climate change research. CICERO Working paper. https://brage.bibsys.no/xmlui/handle/11250/192322

Oliver-Smith, A. (1996). Anthropological research on hazards and disasters. Annual Review of Anthropology, 25, 303-328. https://doi.org/10.1146/annurev.anthro.25.1.303

Pelling, M., \& Uitto, J.I. (2001). Small island developing states: natural disaster vulnerability and global change. Global Environmental Change Part B: Environmental Hazards, 3(2), 49-62. https://doi.org/10.1016/S1464-2867(01)00018-3

Perkins, R.M., \& Krause S.M. (2018) Adapting to climate change impacts in Yap State, Federated States of Micronesia: the importance of environmental conditions and intangible cultural heritage, Island Studies Journal, 13(1), 65-78. https://doi.org/10.24043/isj.51

Persoon, G.A., \& Simarmata, R. (2014). Undoing 'marginality': the islands of the Mahakam Delta, East Kalimantan (Indonesia). Journal of Marine and Island Cultures, 3(2), 43-53. https://doi.org/10.1016/j.imic.2014.11.002

Perumal, N. (2018) "The place where I live is where I belong": community perspectives on climate change and climate-related migration in the Pacific island nation of Vanuatu. Island Studies Journal, 13(1), 45-64. https://doi.org/10.24043/isj.50

Petzold, J. (2018) Social adaptability in ecotones: sea-level rise and climate change adaptation in Flushing and the Isles of Scilly, UK, Island Studies Journal, 13(1), 101118. https://doi.org/10.24043/isj.17

Rapaport, M. (2006). Eden in peril: impact of humans on Pacific island ecosystems. Island Studies Journal, 1(1), 109-124.

Robinson, S.-A. (2018) Adapting to climate change at the national level in Caribbean small island developing states. Island Studies Journal, 13(1), 79-100.

Rudiak-Gould, P. (2013). Climate change and tradition in a small island state: the rising tide. London: Routledge.

Rudiak-Gould, P. (2011). Promiscuous corroboration and climate change translation: a case study from the Marshall Islands. Global Environmental Change, 22(1), 46-54. https://doi.org/10.1016/j.gloenvcha.2011.09.011

Ruosteenoja, K., Carter, T.R., \& Tuomenvirta, H. (2003). Future climate in world regions: intercomparison of model based projections for the new IPCC emissions scenarios. The Finnish Environment, 644, 81.

Schwebel, M.B. (2018) Climate change perceptions and preparation in the United States' territories in the Pacific: American Samoa, Guam, and the Northern Mariana Islands. Island Studies Journal, 13(1), 135-184.

Thompson E. (2008) Acceptance speech by Senator Elizabeth Thompson recipient of 'The Champion of the Earth Award 2008': Latin America and the Caribbean United Nations Environment Programme, Nairobi. 
United Nations (2010). Trends in sustainable development: small island development states (SIDS). New York: UN Press.

UNEP (2014). Emerging issues for small island developing states: results of the UNEP Foresight Process. Nairobi: UN Press.

UN-News (2017). "To deny climate change is to deny a truth we have just lived" says Prime Minister of storm-hit Dominica. UN Reports, September. https://news.un.org/en/story/2017/09/566742-deny-climate-change-deny-truthwe-have-just-lived-says-prime-minister-storm-hit

Walsh, K.J.E., McInnes, K.L., \& McBride, J.L. (2012). Climate change impacts on tropical cyclones and extreme sea levels in the South Pacific: a regional assessment. Global and Planetary Change, 80/81, 149-164.

Walshe, R.A., Chang Seng, D., Bumpus, A., Auffray, J. (2017). Perceptions of adaptation, resilience and climate knowledge in the Pacific: the cases of Samoa, Fiji and Vanuatu. International Journal of Climate Change Strategies and Management, 10(2) 303322.

Walshe, R.A. \& Nunn, P.D. (2012). Integration of indigenous knowledge and disaster risk reduction: a case study from Baie Martelli, Pentecost Island, Vanuatu. International Journal of Disaster Risk Science, 3(4), 185-194. https://doi.org/10.1007/s13753-0120019-x

Watsuji, T. (1988) Climate and culture: a philosophical study. Tokyo: Hokuseido.

Webb, A.P., \& Kench, P.S. (2010). The dynamic response of reef islands to sea-level rise: evidence from multi-decadal analysis of island change in the Central Pacific. Global and Planetary Change, 72(3), 234-246. https://doi.org/10.1016/j.gloplacha.2010.05.003

Weickmann, L., \& Seybold, A. (1940). Climate, weather, and man. Leipzig: Limpert and Quelle \& Meyer. 